Int. J. Dev. Biol. 52: 249-258 (2008)

doi: $10.1387 / \mathrm{ijdb} .072350 \mathrm{jk}$

\title{
Acquisition of cell polarity during cell cycle and oral replacement in Tetrahymena
}

\author{
JANINA KACZANOWSKA*, SZYMON KACZANOWSKI ${ }^{1}$, MAURYLA KIERSNOWSKA, HANNA FABCZAK², \\ KAROLINA TULODZIECKA and ANDRZEJ KACZANOWSKI \\ Department of Cytophysiology, Institute of Zoology, Warsaw University, ${ }^{1}$ Institute of Biophysics and Biochemistry P A N and \\ ${ }^{2}$ Nencki Institute of Experimental Biology P A N, Warsaw, Poland
}

\begin{abstract}
The aim of this study was to search for a mechanism responsible for the acquisition of cell polarity in a ciliate Tetrahymena. Homologs of the mammalian genes coding for CDC42GSK3 $\beta$ - MARK/PAR1-MAPs proteins were found in the Tetrahymena genome (Eisen et al., 2006, and this study). These proteins belong to a pathway which controls assembly and disassembly of microtubule bundles and cell polarity in neural cells. In Tetrahymena, there are two types of morphogenesis: divisional and oral replacement (OR). In divisional morphogenesis, an elongation of longitudinal microtubule bundles (LMs) takes place during cell division. In contrast, in OR type morphogenesis, which occurs in starved non-dividing cells, a polar retraction of LMs occurs. In $T$. pyriformis, the frequency of developmental switch to OR morphogenesis increases in the presence of wortmannin, an inhibitor of the CDC42-GSK3 $\beta$-MARK pathway. In contrast, wortmannin when applied to dividing cells does not affect divisional morphogenesis. Using immunostaining with the antibody against mammalian mitotic phosphoproteins (MPM-2) we show that these proteins co-localize with the LMs and are distributed along the anterior-posterior gradient. In addition, we show that during OR type morphogenesis, the fate of LMs correlates with the anterior-posterior gradient of instability of the cortical structures. We used the conditional mouthless mutant of $T$. thermophila (Tiedtke et al., 1988) to test if the presence of the oral apparatus is required for the maintenance of cell polarity. We discuss our results in relation to the hypothesis of GSK3- $\beta$-MARK pathway involvement in the acquisition of cell polarity in Tetrahymena.
\end{abstract}

KEY WORDS: Tetrahymena, polarity, cytoskeleton, MARK, armadillo

The Tetrahymena (like other ciliates) is a permanently polarized cell. Longitudinal ciliary rows (CR) define its anterior-posterior axis and a sub-apically located oral apparatus (OA) marks its ventral side. The position of other cortical structures depends on the position of the oral apparatus (Frankel 1999) (Fig. 1A and Fig. 7A). In Tetrahymena the spatial deployment of the cytoskeletal proteins is under genetic control of a mechanism of global positioning (Kaczanowski 1975, Williams et al., 1987, JerkaDziadosz et al., 1995, Kaczanowska et al., 2003, StrzyzewskaJowko et al., 2003). The aim of the present study was to gain an insight into the mechanism responsible for the acquisition and maintenance of cell polarity, during morphogenesis of Tetrahymena.

In Tetrahymena there are two types of morphogenesis: divisional and oral replacement (OR). The cortex of Tetrahymena contains a regular array of polarized longitudinal microtubular bands (LMs) running next to meridians of the rows of basal bodies. The assembly of LM-bands is unidirectional (Allen 1967; Ng 1978 , 1979; $\mathrm{Ng}$ and Frankel, 1977) and they play an important role in divisional morphogenesis as a putative cytospindle (JerkaDziadosz et al., 1995). The anterior-posterior axis is preserved during cell division that results in anterior and posterior offspring (Frankel et al., 1981; Frankel 1989; Kaczanowska et al., 1993;

\footnotetext{
Abbreviations used in this paper: AF, anarchic field of oral primordium; CR, ciliary rows of basal body units; CVP, the contractile vacuole pore located at the posterior area of the cell to the right of the ventral side; EHT, end of heat treatment; LM, Longitudinal microtubule bands; nOA, newly formed oral apparatus that appears during oral replacement morphogenesis; OA,oral apparatus; OA1, parental oral apparatus; OA2, new oral apparatus for posterior daughter cell; OR, oral replacement; RM, remnant of engulfed and regressed anterior oral apparatus.
}

\footnotetext{
*Address correspondence to: Janina Kaczanowska. Dept. of Cytophysiology, Institute of Zoology, Warsaw University, Warsaw, Poland. e-mail: kaczan@biol.uw.edu.pl
}

Published online: 8th February 2008. 
A
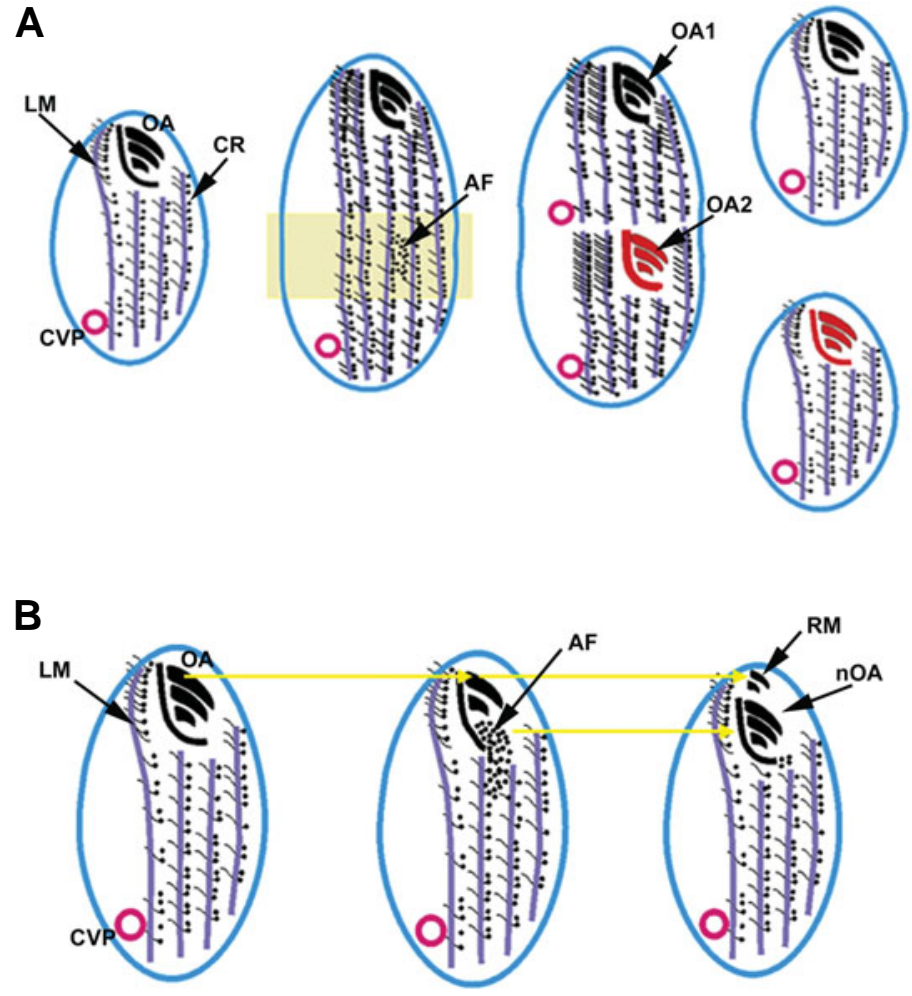

Fig. 1. Diagrams of the two types of morphogenesis in Tetrahymena. (A) Cortical patterns during segmental divisional morphogenesis. (B) Cortical patterns during oral replacement (OR) morphogenesis.

Nelsen et al., 1994) (Fig. 1A). Prior to cytokinesis, the LM- bands maintain their continuity until the fission line separates them. Eventually, after the cytokinesis, the apical band reforms (JerkaDziadosz et al., 2001; Thazhath et al., 2002; 2004). Thus the parental cell undergoes continuous unidirectional elongation in the middle region of the parental cell with the local intercalation of basal bodies and the in situaddition of microtubular subunits into the LM-bands; the process which is consistent with Frankel's (1989) model of "the continuum growth cylinder". During early divisional morphogenesis the new unciliated basal bodies are added into ciliary rows. There are two "gradients" of this addition process: the anterior-posterior (Nanney 1975; Kaczanowski, 1978; Frankel etal., 1981) and the circumferential gradient (Kaczanowski, 1978). In the nascent posterior daughter cell, the new oral primordium appears to the left of the postoral ciliary row \#1 as an "anarchic field of basal bodies" (AF) (Fig. 1A). Its position corresponds to the site of the intersection of both gradients of the proliferation of the basal bodies (Kaczanowski, 1978). This anarchic field develops into the oral apparatus, which, at its anterior, contains fission line that runs perpendicularly across all ciliary rows (Frankel et al., 1981; Nelsen et al., 1994; Kaczanowska et al., 1999; Strzyzewska-Jowko et al., 2003) (Fig. 1A). This segmental pattern of cortex development is synchronized with a bipolar micronuclear mitosis in T. thermophila and with a bipolar macronuclear "amitosis" in both T. thermophila and T. pyriformis (reviewed by Frankel, 1999).

In Tetrahymena, the submembrane skeleton containing at least three epiplasmic proteins EpiA, EpiB and EpiC (Williams et al., 1995) and at least two $\mathrm{Ca}^{2+}$ binding proteins, (Hanyu et al., $1995 ; 1996)$ forms the continuous (with the exception of areas occupied by the microtubule composed structures) cortical shell (Williams et al., 1990). Full knockout of the EPC1gene influences both cell shape and the fidelity of cortical development (Williams, 2004). Epi $B$ protein is absent in the areas occupied by the oral apparatus, the LM-s, the all basal bodies and the contractile vacuole pores (Williams et al., 1990, Williams et al., 1995) (Fig. $2 A)$. Thus in cells immunostained with the anti-EpiB antibody the spatial deployment of cortical microtubules is visible as the unstained "negative" pattern. Prior to cytokinesis, the decrease in the level of Epi B protein follows two segmental gradients in the shell of the apical regions of the parental cell and in the corresponding region of the opisthe (Fig. 2B; Kaczanowska et al., 1993). In contrast, the "fenestrin protein", the other member of the membrane skeleton transiently appears in apical areas of both nascent offsprings (Nelsen et al., 1994; Kaczanowska et al., 2003).

Another type of morphogenesis, called the oral replacement (OR) occurs without cell division within a single Tetrahymenacell. In starved Tetrahymena the oral replacement occurs through a gradual regression and engulfement of the pre-existing oral apparatus at the apical area with the simultaneous morphogenesis of a new oral apparatus just posterior to the old one (Frankel, 1967; 1969; 1970; Williams and Frankel, 1973; Williams and Nelsen, 1973; Kaczanowski, 1976) (Fig. 1B, nOA). This new pole resumes the immunoreactivity with the apical pole marker (fenestrin), which coincides with the patterned polar withdrawal of Epi B immunoreactivity (Kaczanowska et al., 2003) (Fig. 2C). During oral replacement of the starved Tetrahymena there is exchange and flux of stable subunits of microtubules, which is controlled by newly synthesized MAPs (Williams and Nelsen, 1973). The two types of Tetrahymena morphogenesis are summarized in Fig. 1 A, B and Fig. 2 A-C.

In this study, we asked whether the re-formation of an anteriorposterior axis and the ventral positioning of the oral apparatus occurring during Tetrahymena morphogenesis are controlled by CDC42- GSK3 $\beta$-MARK pathway regulated by a nutritional signal. It is known that this pathway is involved in the generation of cell polarity in metazoan neural cells (Doble and Woodgett, 2003) and non-neural cells (Etienne-Manneville and Hall, 2003). In differentiating neural cells, the effector mechanism for the establishment of cell polarity involves the cascade of activities of specific kinases. The GSK3 $\beta$ (glycogen synthase kinase 3), and MARK kinase (Microtubule Affinity Regulating Kinase) regulate the lengthening and linear assembly/ dissasembly of the bundles of microtubular subunits during the neuritogenesis through specific phosphorylation of a set of microtubule-associated proteins (MAPs) (Drewes et al., 1997; Johnson and Stoothoff, 2004; Wiggin et al., 2005). The GSK3 $\beta$ kinase activates MARK/PAR1 effector kinase by a structurally directed phosphorylation (Kosuga et al., 2005) and then MARK/PAR1 destabilizes MAPs. This pathway is controlled by CDC42 complex (Cau and Hall, 2005) involved in posterior localization of MARK/PAR1 kinase (Schonegg and Hyman, 2006). Hence, the primary task in Tetrahymenagenome research is the search for the putative genes encoding the CDC42- GSK3 $\beta$-MARK- MAP pathway. If these genes do really exist in Tetrahymenagenome, the putative CDC42, GSK3 $\beta$ (ser9) and MARK/PAR1 proteins should be identifiable on Western blots 
of homogenized Tetrahymenacells with the available commercial antibodies against cognates metazoan proteins.

The next question concerns the character of the upstream components of this signaling pathway. During the neural differentiation of metazoan cells the anterior-posterior gradient of activity of GSK3 $\beta$ renders the stabilized posterior pole and a highly active and structurally unstable, growing anterior cone of the neurite (Biernat et al., 2002). This linear gradient of growth and structural stability of the neurite is induced by the upstream Wnt signaling transmitted to GSK3 $\beta$, and by the posterior location in cell of MARK/PAR1 protein (Doble and Woodgett, 2003). Therefore, we were also searching for the presence of possible orthologs of a Wnt signaling pathway in the genome of Tetrahymena.

The presence or absence of cell polarity during oral replacement (OR) morphogenesis in Tetrahymena can be tested by the use of the MPM-2 antibody against mitotic phosphoproteins. The MPM-2 monoclonal antibody binds to a plethora of phosphorylated proteins present in mammalian basal bodies and the mitotic spindle (Westendorf et al., 1993). Previously we described the cortical patterns and polarity of MPM-2 immunostaining during cell cycle of Tetrahymena (Kaczanowska et al., 1999). Our present studies were focused on the pattern of MPM-2 immunoreactivity in Tetrahymena cells during OR morphogenesis.

In non-neural metazoan cells, the signal upstream of $\mathrm{PI}-3$ kinase drives the activation of Akt kinase regulating the CDC42GSK3 $\beta$-MARK-pathway, which controls the polarity and asymmetry of the cytoskeleton (Ahringer 2003; Doble and Woodgett, 2003). In metazoan cells the specific inhibitor, wortmannin, inhibits activity of the PI-3K pathway and Akt kinase, hence induces abnormal activity of the GSK3 $\beta$ (Kozma and Thomas, 2002). Wortmannin acts on the PI-3K (class I) pathway in $T$. thermophila and T. pyriformis (Leondaritis et al., 2005) affecting, tentatively viainsulin-like signaling (Christensen etal., 2003), the food-vacuole formation (Zackroff and Hufnagel, 2001) and various components of the cytoskeleton (Kovacs and Pallinger, 2003). Since wortmannin arrests degradation of proteins at the initial sequestration step (Petiot et al., 2000), we tested the effects of wortmannin on the divisional morphogenesis of Tetrahymena

Fig. 2. Tetrahymena in two types of morphogenesis. (A-C) Immunostaining with the anti-B epiplasm antibody; "negative" staining is seen, i.e. the cortex remains unstained in the regions occupied by microtubular organelles. (D-F) Anti-MPM2 antibody immunoreactivity; positive staining of phosphoproteins associated with cortical structures of Tetrahymena in OR morphogenesis can be seen. (A) The early dividing cell with a "negative" pattern of cortical microtubules: in the OA1, AF region, basal body ciliary rows and the $L M$-bands. (B) The dorsal side of dividing cells with "negative" pattern of basal body ciliary rows and LMbands, and with diminished immunostaining of apical area in parental cell, and in the area posterior to the fission line. (C) The cell in OR morphogenesis, Region of OA1 and the early anarchic field for new OA2 (AF) remain unstained; note the distinct "negative" pattern of the LM-bands. (D) Cell with extremely strong MPM-2 staining of the engulfed oral apparatus (RM) and with strong immunostaining of the newly formed oral apparatus (nOA) with the moderately immunostained dispersed anarchic field (AF). (E) Cell in OR at an advanced stage; the remnant (RM) of the engulfed oral apparatus is reduced to a strongly shining RM-pocket and some traces of the closed slit; the posterior shining field is subdivided into two entities ( $\mathrm{OA}$ and $n O A$ ?) along the ventral side. (F) Dorsal side of the cell in OR; note very intense and polarized immunostaining of $L M$-bands. pyriformis. Under conditions that increase a propensity for the induction of oral replacements, (Ryals etal., 1997) we studied the effect of wortmannin on the stability of new oral structures for prospective posterior cell and the ability of the post-dividing cells to enter the oral replacement pathway.

We also focused on testing whether the structural presence of the oral apparatus is required for the establishment of anteriorposterior polarity and whether the oral apparatus is a marker for the establishment of the ventral side of cell. In these studies we have used conditional mutant II8G of Tetrahymena thermophilato generate an array of phenotypes with different degree of reduction of oral apparatuses and tested them for the presence of apical markers (i.e fenestrin, and anti B epiplasm)(Nelsen et al., 1994; Kaczanowska et al., 2003).

We also discussed whether the results of our study are consistent with the hypothesis of the CDC42- GSK3 $\beta$-MARK pathway involvement in the generation of the cell polarity during the morphogenesis of Tetrahymena.

\section{Results}

\section{Search of Tetrahymena genome for the components of Cdc42- GSK3beta-MARK pathway}

\section{GSK3ß}

We searched Tetrahymenagenome for the possible homologs of the mammalian gene encoding GSK3 $\beta$ protein. We used the query sequence of human GSK3 $\beta$ (GSK3 $\beta$-human uniprot ID) and the tblastn computer program, provided by the www interface http://tigrblast.tigr.org/er-blast/index.cgi?project=ttg. We found DNA sequence Q248B3-TETH in the Tetrahymenagenome encoding a protein homologous to a GSK3 $\beta$ kinase with an extremely low expected value:3.8e-63. Another blast search showed that all other proteins most closely related to the candidate Tetrahymenagene belong to the family of GSK3 $\beta$ kinases present in various species of animals.

The results of blast analysis prompted us to test the antibody directed against metazoan inactivated GSK3 $\beta$ kinase i.e. the
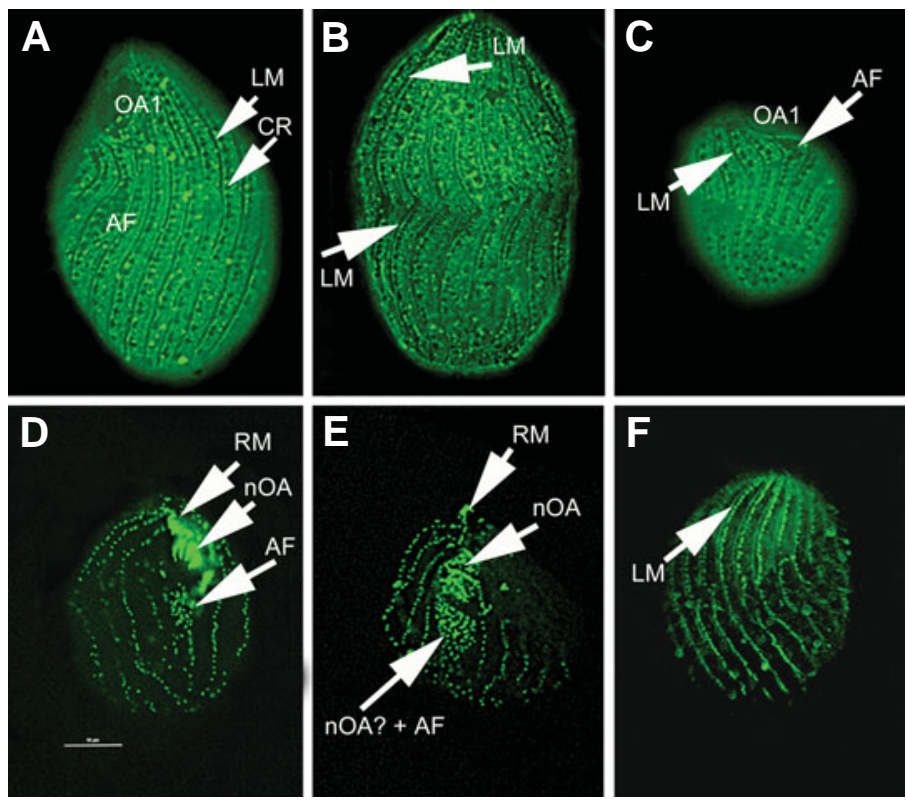
GSK3ß (ser9) (Santa Cruz BT) on Tetrahymena cells. This antibody recognized single protein band of about $47 \mathrm{kD}$ in the homogenate $(\mathrm{L})$ and microsomal $(\mathrm{P})$ fraction of Tetrahymena cells (Fig. 3, arrow).

\section{MARK/PAR1}

According to Eisen et al. (2006) MARKs genes are present in T. thermophila. We carried out the tblastn search in a Tetrahymena genome using www interface http://tigrblast.tigr.org/erblast/ index.cgi? project=ttg and a human sequence of mark1 (uniprot ID mark1-human). We detected the homologous sequence with a very small 4.4.e-43 expected value. This sequence corresponds to the putative sequence of the SNF1 kinase of Tetrahymena(Q22XQ2). Alignment of this sequence with human MARK1 showed sites responsible for activation of phosphorylation 202 and 212 (Kosuga et al., 2005) with corresponding sites in Tetrahymena Q22XQ2, and containing "T" motif typical for human MARK, but without a header sequence for centrosomal localization (Fig. 4) (Tassan and Le Goff 2004). The KIAA human domain of MARK1 is homologous to the KIAA Q22XQ2 domain with expected value $3 e-29$, different human aapk2 and marks kinases (e.g. to human protein $\mathrm{p} 78 / \mathrm{c}$-tak protein. This sequence is similar to the OSK1 protein of Oriza sativa (plant) and to human protein $\mathrm{p} 78 / \mathrm{c}-\mathrm{TAK} 1$, which in mammalian cells sequestrates MARK kinase in a cytoplasm (Peng et al., 1998). The search for Tetrahymena homologs of mouse mark2 (ID MARK2_Mouse) PAR1B detected also many related sequences (Eisen et al., 2006).

Western blot analysis of the total homogenate and the microsomal fraction of Tetrahymena cells demonstrated that the antibody raised against $\mathrm{C}-\mathrm{TAK} 1$ recognizes a single $36 \mathrm{kD}$ protein band (Fig. 5, arrow). Peng et al. (1998) reported that c-tak1 protein is cleaved at its $\mathrm{NH}_{2}$ and $\mathrm{COOH}$-terminal ends to generate the $36 \mathrm{kD}$ catalytic domain. It is possible that similar process occurs in Tetrahymenaand that $36 \mathrm{kD}$ band represents a cleaved product. So far we were unable to visualize the presence of this kinase in the LM-bands in Tetrahymena.

\section{CDC42}

This GTPase is a common component of the GSK3 $\beta$-MARK pathway (Cau and Hall, 2005) which is possibly involved in the localization of MARK/PAR1 kinase at the posterior pole of the polarized metazoan cells. A gene coding for putative small GTPbinding protein closely related to CDC42 proteins (uniprot ID Q23GR6-TETTH) was found in the Tetrahymenagenome. When

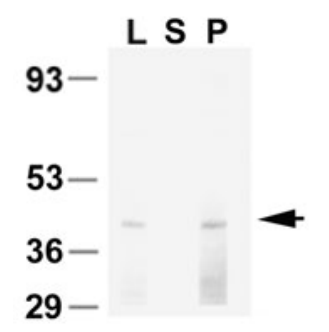

Fig. 3. Western blot of Tetrahymena pyriformis with antibody against GSK3ß-Ser 9 inactivated kinase (Santa Cruz BT, Santa Cruz, California, USA) indicates the presence of single $47 \mathrm{kD}$ protein band. Total homogenate (L), cytosolic (S) and microsomal (P) fractions.

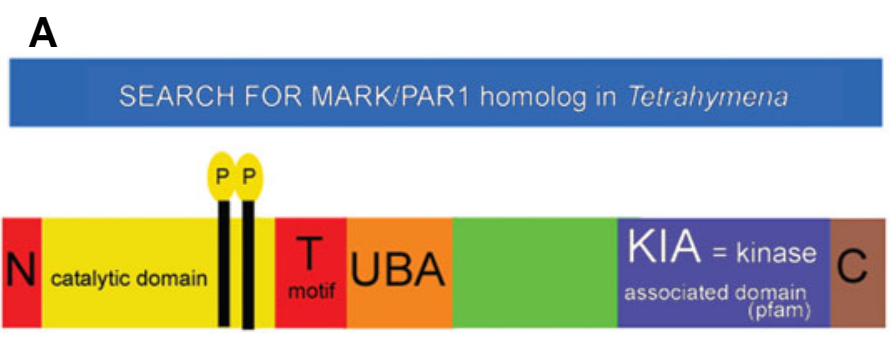

B

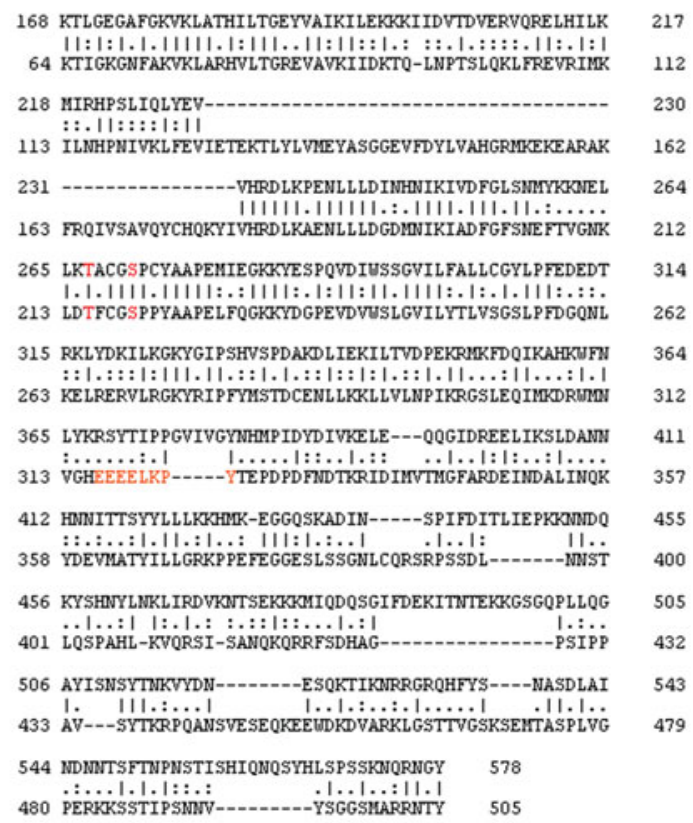

Fig. 4. (A) MARK kinase domains and (B) partial alignment of the human and Tetrahymena thermophila MARKs indicating in colours the essential phosphorylation sites and T-motif.

we carried out a blastp search against the uniprot data base we detected sequence with strong homology to the genes coding for animal CDC42 proteins. The candidate gene was also homologous to CDC42 of Schizosaccharomyces pombe with expected value $2 \mathrm{e}-52$. Immunoblot analysis of Tetrahymena cell homogenate and microsomal material with monoclonal antibody against CDC42 showed a single $29 \mathrm{kD}$ protein band (Fig. 6 arrow).

\section{MAPs: Search for MAP1B, MAP2, tau and MAP4}

These proteins contain PFAM domain tubulin binding repeat and are exclusively metazoan. We carried out a tblastn search in Tetrahymenagenome using www interface http://tigrblast.tigr.org /er-blast/index.cgi?project=ttg and a sequence of human MAP1B (uniprot ID MAP1B_Human) and we detected a low complexity homologous sequence with a very high expected value (0.11). The same search with a sequence for human MAP2 protein (uniprot ID MAP2_Human) also detected a homologous sequence with a very high expected value (0.46). Search for the human tau protein (uniprot ID Q5XWF0) detected a low complexity sequence with expected value 0.99 . Finally, a search for the human MAP protein 4 (uniprot ID MAP4_Human) detected a low complexity sequence with expected value 0.67 . Western blot with anti-tau5 (anti-five isoforms of tau) antibody also yielded a negative result (not shown, Matui et al., 2004). 
Therefore in agreement with previous report (Eisen et al., 2006) it is unlikely that Tetrahymenagenome is encoding MAP1B, MAP2, tau and MAP4 proteins.

\section{MAPs of Tetrahymena}

So far there are two identified MAPs that are able to bundle subunits of microtubules in experimental assay (Matui et al., 2004). These are: the GAPDH protein and another protein probably corresponding to the fragment of the XMAP 215 microtubuleassociated protein participating in the formation of the mitotic spindle in Xenopus cells. Eisen et al. (2006) reported in Tetrahymena two sequences of XMAP215: TTHERM_00439010 and TTHERM_00488190. Matui et al. (2004) also found another MAP in Tetrahymena, which has not been characterized yet.

In summary the in silico search of sequenced Tetrahymena thermophila genome (TIGR http://www.tigr.org/tdb/e2k1/ttg/) identified the orthologs of the GSK3 $\beta$ - MARK2/PAR1/kin1 pathway. The corresponding bands were also detected in fractionated Tetrahymenaby Western blotting with metazoan antibodies (Figs. $3,5,6)$.

Search of Tetrahymena genome for upstream components of Wnt signaling. Dishevelled and axin mediate upstream signaling cascades to regulate cell polarity in metazoa (Wallingford and Habas, 2005; Jiang et al., 2005). We used as a query, the sequences for human dishevelled (uniprot ID dvl1_human) and human axin (uniprot ID axn1_human). These proteins contain smart domain dax. This is exclusively animal domain according to smart server, and therefore, as expected, we were unable to detect any homologous sequences in Tetrahymena genome.

\section{$\beta$ - catenin}

First, we searched for the gene encoding $\beta$ catenin in Tetrahymena genome using the tblastn computer program provided by www interface http://tigrblast.tigr.org/erblast/index.cgi?project=ttg using the sequence of Drosophila $\beta$-catenin (ARM_DROME uniprot ID). We were unable to detect any homologous sequences in the Tetrahymena genome.

The catenin protein contains many armadillorepeats. Using a

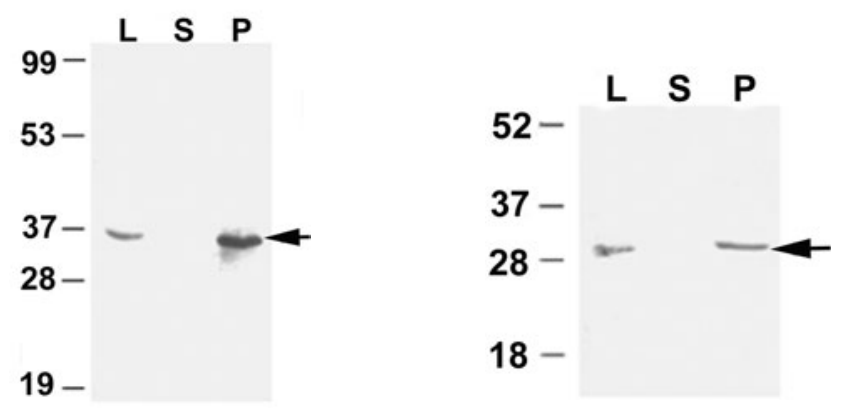

Fig. 5 (Left). Western blot of Tetrahymena pyriformis with polyclonal c-tak1 antibody against MARK/78kD (Upstate, Lake Placid, NY, USA) and developed by ECL. Total homogenate (L) and cytosolic (S) or particulate (mirosomal) (P) fractions; arrow points to the specific $36 \mathrm{kD}$ band.

Fig. 6 (Right). Western blot of Tetrahymena pyriformis fractions with monoclonal antibody against cdc-42 (Santa Cruz BT, Santa Cruz, California, USA) recognizes the protein band of about $29 \mathrm{kD}$. smart server http://smart.embl-heidelberg.de/ we identified a putative protein in Paramecium containing many armadillo repeats (Q6BGJ0_PARTE). When we used this sequence as a query and we carried out blast search against the uniprot database we detected homology to the different importines including human $\alpha 6$, (IMA5-HUMAN uniprot ID), plant MOS6 (Palma et al., 2005) and 8 different importins in Tetrahymena.

Search for PAR6 with PAR6 $\alpha$ as a query. PAR6 protein is a fusion of widely distributed smart domains (PB1 and PDZ). According to smart server http://smart.embl-heidelberg.de/ this type of fusion is present only in metazoan genes and is absent in Tetrahymena.

In summary, we concluded that the upstream components of a Wnt signaling pathway are not present in T. thermophilagenome. In addition, it is likely that in Tetrahymena, the proteins with armadillo repeats may have totally different functions than $\beta$ catenin.

\section{Morphological observations on re-polarization events in di- viding cells and in cells in oral replacement}

In mammalian cells the GSK3- $\beta$ controls the mitotic spindle dynamics that is suppressed by such inhibitors like the lithium chloride (Wakefield et al., 2003). We tested the spatial distribution of mitotic phosphoproteins (detected by MPM-2 antibody) in cells in OR. Kiersnowska and Golinska (1996) found a very weak phosphorylation of the LM-bands in the morphostatic cells in contrast to the strong staining of LM-bands in cells in OR (Fig. 2F). The area of the regressing and engulfed anterior region (Fig. $2 \mathrm{D}, \mathrm{E} ; \mathrm{RM}$ ) and the area of newly produced parts of the oral apparatus (Fig. 2 D, E; nOA) immunostained very strongly with the MPM-2 antibody. The posterior anarchic field of basal bodies (Fig. 2D; AF) showed lower intensity of immunostaining but stained more intensely than the basal bodies in ciliary rows at the posterior part of the cells. At the more advanced stage of oral morphogenesis (Fig. 2E) a strong fluorescence visible at the apical area corresponded to the remnant (RM) of the engulfed OA1 and the new OA (Fig. 2E; nOA). In addition, an anteriorposterior gradient of fluorescence of the abnormally organizing additional oral apparatus and fluorescence of AF were also visible (Fig. 2E; nOA?+AF). In some cells in OR, their dorsal side showed an anterior-posterior gradient of the immunostaining of the LMbands (Fig. 2F; LM).

All these results are consistent with the hypothesis that the LMbands and the oral structures in Tetrahymena undergo certain spatial and cell cycle determined changes which correlate with the anterior-posterior intensity of fluorescence of the antibody against MPM-2 phosphoproteins.

\section{Studies on the effects of wortmannin on synchronized Tet- rahymena pyriformis}

Frankel (1967) and Frankel and Williams (1973) found that in Tetrahymena, the progress of the cell cycle and the acquisition of cell polarity depend on the external signals of nutrition and that the starved cells are mitotically arrested. The effects of wortmannin, the inhibitor of PI-3 kinase pathway was tested in synchronized $T$. pyriformis in constant presence of $1 \%$ PPY, the chelated $\mathrm{Fe}$ chloride and salts. The data are presented in Table 1. These data indicate that wortmannin added $30 \mathrm{~min}$ or later after the end of synchronizing treatment (EHT) does not affect the morphology, 
with the exception of the enlargement of the forming OA2 (Fig. $7 A, B$ ) or the timing of synchronous cytokineses (approximately 90 min after the EHT the $25 \%$ of cells were in cytokinesis). After the cytokinesis the post-divided and rounded cells still lacked of internal part of cytopharynx, i.e. the deep fiber structures, which usually are produced 20-30 min after cytokinesis. In two types of treated samples (30-90 minutes, and 50-90 minutes), fixed at the time of synchronous cytokinesis, about $50 \%$ of cells were in the stages corresponding to the OR morphogenesis. Thus, it seems that the post-dividing cells and possibly the undivided cells (cells in synchronous rounding stage; Frankel, 1967) without internal part of cytopharyx start the oral replacement synchronously. Usually most of these cells form a single new oral replacement primordium (Fig. 7D), but some cells form a series of primordia in an anterior-posterior order with a tendency to curl the ciliary row \#2 located posterior to OA1 that is reduced to a remnant engulfed pocket (Fig. 7C). Such behavior of ciliary rows \#2 and rows n-1 and $n-2$ strongly suggest that the position of the newly formed apex become established at the posterior end of the disappearing OA1. Another type of cells was also present in wortmannin treated samples; these were mouth-less cells with an enlarged anarchic field (AF) of basal bodies marking the ventral side of the cell (Fig. $7 \mathrm{E}, \mathrm{F})$.

\section{Analysis of the phenotypes of II8G mutant of Tetrahymena thermophila}

We used anti-Epi B and anti-fenestrin antibodies to test polarity of II8G conditional mutant cells in different stages of morphogenesis. Overall, the II8G mutant cells kept in conditions yielding mutated phenotype were much smaller than control cells, but a subpopulation of mutant cells had normal size (Fig. 8 A,B). The mouth-less cells were descendants of dividing cells with underdeveloped OA2 (not shown) or cells with more or less advanced engulfment of the anterior oral apparatus. In IIG8 cells the process

\section{TABLE 1}

\section{EFFECTS OF WORTMANNIN TREATMENT ON ORAL DEVELOP- MENT IN SYNCHRONIZED T. PYRIFORMIS}

\begin{tabular}{cccccccc} 
& \multicolumn{7}{c}{ Stages of development } \\
$\begin{array}{c}\text { Time of } \\
\text { treatment }\end{array}$ & st. 0 & st. 1-2 & st. 3-4 & st. 5 & st. 6 & OR & $\begin{array}{c}\text { astomatous } \\
\text { and others }\end{array}$ \\
\hline $\begin{array}{c}\text { Control: Time after EHT } \\
50^{\prime}\end{array}$ & 18 & 60 & 10.5 & 8 & 1 & 2.5 & - \\
$90^{\prime}$ & 38 & 6 & 10 & 1 & 45 & - & - \\
$120^{\prime}$ & 96.5 & & 0.5 & 0.5 & 2.5 & - & - \\
Wortmanin added and fixed & & & & & & \\
$30-50^{\prime}$ & 45 & 12.5 & 35.5 & 0.5 & 0.5 & 3 & 3 \\
$30-70^{\prime}$ & 53 & 2 & 2 & 1 & 16 & 26 & - \\
$30-90^{\prime}$ & 16.5 & 0.5 & 2,75 & 1,75 & 21,15 & 56 & - \\
$30-120^{\prime}$ & 75 & 0.5 & 2,15 & - & - & 22 & - \\
$50-70$ & 26 & 11 & 22 & 1 & 15 & 25 & - \\
$50-90^{\prime}$ & 29 & & 18 & 1 & - & 50 & 2 \\
$50-120$ & 43.5 & 7 & 10 & - & - & 38 & 1.5 \\
\hline
\end{tabular}

Effects of wortmannin treatment $(2 \mu \mathrm{g} / \mathrm{ml})$ on the progress of divisional morphogenesis and on the appearance of the oral replacement phenotypes in synchronized Tetrahymena pyriformis.

Times of addition of wortmannin and sample fixation indicate time in minutes that elapsed after EHT. Percentages of morphological stages counted in sample of about 200 well stained specimens
A
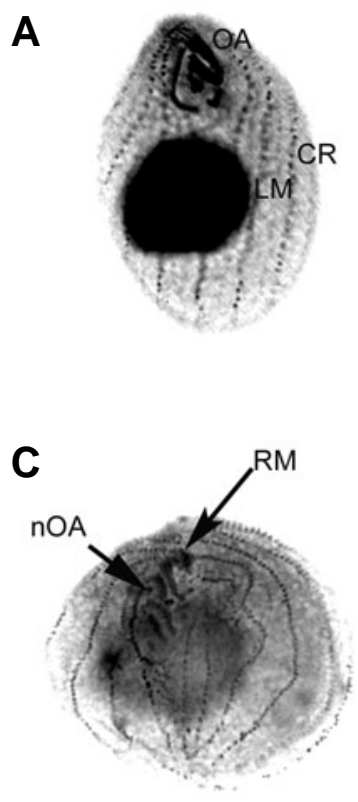

E

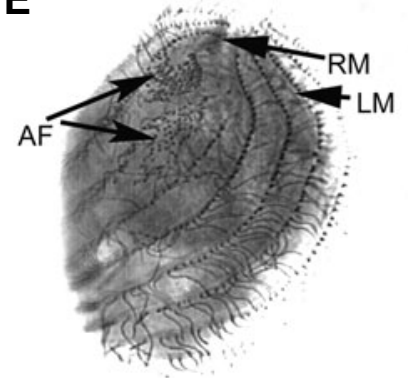

B

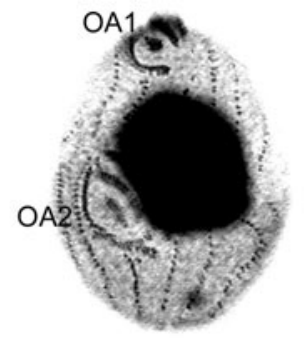

D
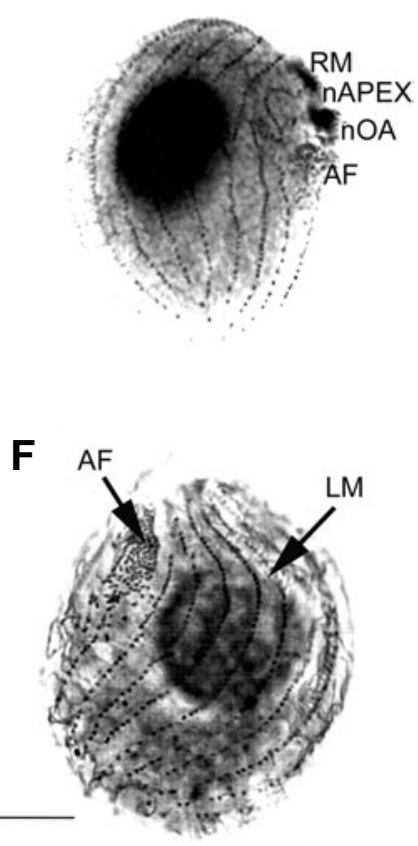

Fig. 7. Morphogenesis of synchronized T. pyriformis prone to enter into oral replacement morphogenesis treated with wortmannin 30 min after the end of heat treatment (EHT). Protargol stained specimens. (A) The interphase cell showing normal morphology. (B) The dividing cell fixed about 50 min after EHT showing normal morphology, except that OA2 is enlarged; (C-F) cells were fixed 120 min after EHT. (C) Cell in oral replacement morphogenesis with the engulfed regressed oral apparatus reduced to the remnant pocket (RM) and with developing new oral apparatus ( $n O A)$. (D) Cell at the same stage as shown in (C) but in side view; note: the rim of the remnant pocket, the membranellar cilia of the new oral apparatus (nOA) and the newly produced apex (nAPEX) with posterior position of the anarchic field (AF). (E) The mouth-less cell with its longitudinal microtubule (LM) bands, with the anterior residual remnant pocket (RM) and with two parts of the ventral anarchic field (AF). (F) Mouth-less cell with a single anarchic field (AF), and with two post-oral shortened ciliary rows marking ventral side of this cell.

of regression of apex and accompanying LMs and oral structures results in the formation of temporary pocket-like structure. We found that the border (slit) of this pocket is positive for the presence of EpiB (Figs. 8 C,D). After the completion of the resorption of old apex and the disappearance of the pocket-like structure, EpiB staining disappear and a new apex becomes temporarily positive for the presence of fenestrin (see below, Fig. $8 \mathrm{H})$ 
The results of fenestrin immunostaining of II8G cells (Fig. $8 \mathrm{E}-\mathrm{H}$ ) were also instructive. Some of the II8G cells showing the apical fenestrin staining (Fig. 8E; APEX) are either in the particular stage of the resorption of anterior oral apparatus or in the early stages of the development of the posterior oral structures (Fig. 8E; OA?, nOA? and AF?).One of the cells in cytokinesis shows the anterior cell with the slightly engulfed oral apparatus with apical fluorescence signal indicating presence of fenestrin, and the posterior mouth-less cell also with a very strong apical signal for fenestrin (Fig. 8F; APEX). Fig. 8 (G,H) shows two small cells without oral apparatuses. These cells have strong signal of apical fenestrin (Fig. 8 $\mathrm{G}, \mathrm{H} ; \mathrm{APEX}$ ), and a very weak immunostaining of some ciliary rows at more distant positions.

All these observations indicate that the presence of the anterior oral apparatus is not required for the appearance of the fenestrin at the anterior pole, and that the engulfed slit is a marker of the ventral side of mouth-less cells.

\section{Discussion}

The first part of this study described the identification of the components of CDC 42GSK3 $\beta$-MARK pathway in a ciliate $T$. thermophilagenome and tested their relationship to the upstream Wnt signaling pathway (as observed in neural metazoan cells, reviewed by Doble and Woodgett, 2003). From the search in silico of the sequenced genome of Tetrahymena thermophila (TIGR http:// www.tigr.org/tdb/e2k1/ttg/) we identified the orthologs of the GSK3 $\beta$ - MARK2/PAR1 pathway. Some of the components of this pathway were also identified by Western blotting of fractionated Tetrahymena, using commercial antibodies against cdc42, mammalian GSK3 $\beta$ (ser9), and mammalian MARK $/ 78 \mathrm{kD}$. The upstream components of a Wnt signaling pathway were not found in T. thermophila genome. On the other hand we found in Tetrahymena a subset of proteins with armadillo repeats, which may play totally different role than $\beta$ catenins.

In non-neural metazoan cells, upstream of GSK3 $\beta$, the PI-3kinase-related signaling drives the activation of Akt kinase that controls polarity through the stabilization of structural bundling between MAPs and microtubules (Ahringer 2003; Doble and Woodgett, 2003). Accordingly, in synchronized T. pyriformis the addition of the inhibitor (wortmannin) to this pathway yielded the dividing cells with enlarged new oral apparatus, which were prone to enter into an oral replacement morphogenesis (Fig. $7 \mathrm{~A}-\mathrm{F}$ ).

We also wanted to determine whether the appearance of cell polarity during morphogenesis of Tetrahymena correlates with the gradient of structural stability of cortical microtubules, which might be controlled by the GSK3 $\beta$-MARK pathway. There are
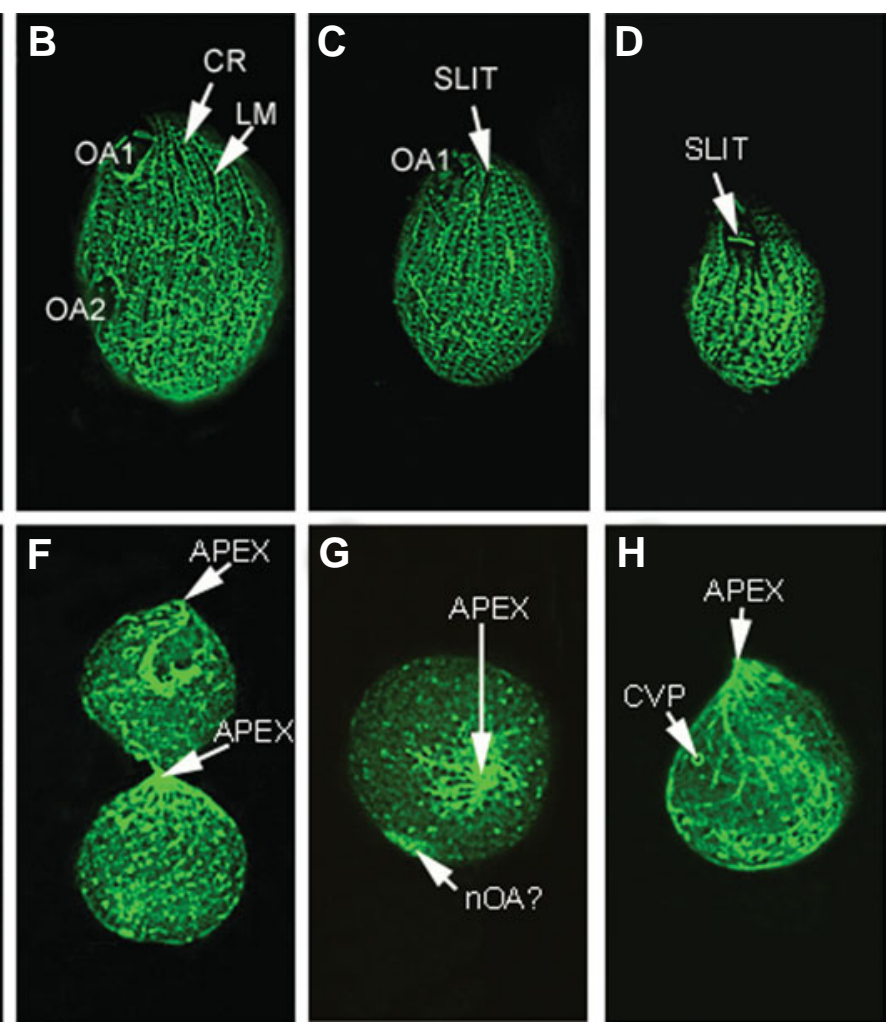

Fig. 8. The II8G phenotypes of Tetrahymena thermophila. (A-D) Specimens immunostained normal cortical pattern is negative at the subapical OA area, along the LM-bands, and in the (B) Cell of a normal phenotype at an early stage of divisional sthe anterior oral apparatus (shining SLIT) and with the apical region totally unstained. (E-H) I/8G specimens immunostained with the anti-fenestrin antibody. (E) with a shining apical pole (APEX) with a series of engulfing OA (OA?), a newly processed Mouth-less cell showing strong apical staining (APEX), residual diffused ventral staining and the single contractile vacuole pore (CVP).

some indirect evidences that support the hypothesis of the involvement of GSK3 $\beta-M A R K$ pathway in cortex stability. JerkaDziadosz and Frankel (1995) showed that in Tetrahymena, during divisional morphogenesis, the lithium chloride, the inhibitor of GSK3 $\beta$, affects the organization of opistor oral structures.

Williams and Nelsen (1973) correlated turnover of microtubule proteins with oral replacement. It is possible that deficience of MAPs brings about decreased stability of cytoskeletal structures and increased propensity of starved cells for OR morphogenesis.

In this study we showed that the anterior-posterior difference in intensity of MPM-2 immunostaining correlates with the changes in the structural stability of microtubular organelles. At the anterior pole, both LM-bands and parts of the "old" oral apparatus were extremely unstable and underwent regression, the neighboring posterior area was also unstable, undergoing futile attempts to organize oral structures, whereas the posterior pole seemed to be normal (Fig. 2D-F). This was reminiscent of $T$. thermophila phenotypes observed in cells with the EPC1 gene (epiplasm C 
protein) gene knockout (Williams, 2004). This suggests (but does not prove) that during starvation of a wild type cells, or in mutants (mouth-less II8G and EPC1 knockout cells) the gradient of structural stability is present along the anterior-posterior axis of cells. At the anterior apical cortex, the regression and instability of microtubules and microtubule-associated structures and epiplasm are very high. The moderate structural stability is sufficient for attempts to form the new oral apparatus posterior to the apical zone. The posterior pole appears to be the most stable cortical zone. Studies with apical markers (Kaczanowska et al., 2003) were consistent with the hypothesis that in the mouth-less cells (both after wortmannin treatment and in II8G phenotypes) the apical fenestrin immunostaining was independent of the presence of an oral apparatus. Nevertheless, some II8G phenotypes showed a spiraling of the LM- bands and associated ciliary rows. This indicates that the structural stability of the oral apparatus in Tetrahymena enforces a cylindrical pattern of cell growth.

The question arises whether this anterior-posterior spatial arrangement of regions of increasing instability of cortical structures represents the polar gradient of activation of some proteolytic activity in Tetrahymena? In this context MARK kinases with UBA domain (Fig. 4A) and c-TAK1 kinase which function depends on the ubiquitinating factor (Peng et al., 1998; Wang et al., 2001) are the first indications of a putative involvement of these kinases, or their upstream regulators in the mechanism of setting up cell polarity in Tetrahymena during OR. In polarized metazoan cells the MARK/ PAR1 kinase is active at early step of embryonic axis formation (La Carbona et al., 2004) and is inactive at the posterior pole that is more resistant to proteolysis (Benton and St.Johnston, 2002). The GSK3 $\beta$-MARK-MAPs pathway also controls changes during mitotic cycle (Drewes and Nurse, 2003). It seems that the OR morphogenesis in starved Tetrahymenawith anterior retraction of LMs and associated apical structure may parallel the events occurring during polar retraction of neurites in axon pruning events in neural cells (Hoopfer et al., 2006).

In conclusion our data support hypothesis that GSK3 $\beta$-MARKMAPs pathway may be involved in setting up a global cell polarity in a ciliate Tetrahymena.

\section{Materials and Methods}

\section{Strain culture and synchronization}

Tetrahymena thermophila CU428.1 (MPR1, ms, mt VII) were kindly provided by $\mathrm{Dr}$ J.Gaertig (originally derived from Cornell University, U.S.A.), and Tetrahymena pyriformis (GL-C) was kindly provided by $\mathrm{Dr}$ J.Nilsson (University of Copenhagen, Denmark). These strains were routinely cultured in $1 \%$ proteoso-peptone (Difco) and $0.1 \%$ yeast extract (1\% PPY) in salt solution with $\mathrm{FeCl}_{3}$ at $28^{\circ} \mathrm{C}$ (Nelsen et al., 1981). Heat shock was applied to T. pyriformis, according to the routine procedure of Zeuthen (Wiliams and Scherbaum, 1959, Nelsen et al., 1981). The end of the seventh shock was designated EHT (end of heat treatment) and all timing thereafter is given in minutes (Table 1).

The mutant II8G homozygous for single mutation in Tetrahymena thermophila (Tiedtke et al., 1988) was a gift from Dr Leif Rasmussen (University of Odense, Denmark). Stock cultures were grown in proteose peptone-yeast extracts supplemented with salts at the permissive temperature of $28^{\circ} \mathrm{C}$. They exhibited wild type phenotype. Experimental cultures were grown at $37^{\circ} \mathrm{C}$ (non permissive temperature) in the same medium supplemented with $1 \mu \mathrm{g} / \mathrm{ml}$ folinic acid and salts of $\mathrm{Fe}^{3+}$ and $\mathrm{Cu}^{2+}$. In this condition cells are able to proliferate yielding small cells with very variable phenotypes including some cells without oral apparatuses and some cells in OR morphogenesis.

\section{Study of the effects of wortmannin on the morphogenesis of $\mathrm{T}$. pyriformis}

These were performed according to the protocol of "synchronous rounding" (Frankel 1967, 1970; Williams and Frankel, 1973) except that T. pyriformis were permanently kept in $1 \% \mathrm{PPY}, \mathrm{FeCl}_{3}$ and salt culture medium, and were given a standard seven shock heat synchronizing treatment. Control samples served to test the occurrence of the OR morphogenesis without the drug, whereas the experimental samples contained wortmannin (dissolved in DMSO) in final concentration of $2 \mu \mathrm{g} /$ $\mathrm{ml}$. Wortmannin was added at $30 \mathrm{~min}, 50 \mathrm{~min}$ and $70 \mathrm{~min}$ after EHT i.e. when cells entered into divisional morphogenesis. The results of two different experiments containing cells with a high propensity for oral replacement after wortmannin treatment are shown in Table 1.

\section{Permanent preparations}

Protargol staining was performed according to routine protocol (Kaczanowska et al., 1993). The preparations were used for analysis of the fractional distributions in different morphogenetic stages in accordance with accepted morphological criteria for divisional morphogenesis and for the oral replacement (Frankel,1967; Williams and Frankel, 1973).

\section{Immunostaining}

The following antibodies were used: the MPM-2 antibody against a set of the mammalian mitotic phosphoproteins (1:200 dilution;gift from $\mathrm{Dr}$ P.N.Rao, Boulder, Colorado, U.S.A.), the anti B epiplasm serum (1:100 dilution; gift from Dr. N.E. Williams, lowa University, U.S.A.) and the antifenestrin antibodies (9a7 against $T$. thermophila and 3A7 against $T$. pyriformis, both in dilution 1:40; (gifts from Drs J. Frankel and N. Williams, lowa University, U.S.A.). Immunostainings was performed exactly as described earlier (Kaczanowska et al., 1993; 1999; 2003).

Four commercial antibodies were also used: anti- tau5 (1:1000 dilution; Chemicon, Ternecula,California, USA)), anti-GSK3 $\beta$ (ser9) (1:500 dilution; Santa Cruz BT, Santa Cruz California, USA), anti-C-TAK1 (1:500 dilution; Upstate, Lake Placid, NY, USA) and anti-cdc42 (1:1000 dilution; Santa Cruz BT, Santa Cruz, California, USA). Storage and handling of antibodies were done according to donators' or manufacturers' protocols.

\section{Cell fractionation}

Cells were fractionated according to the method of Bollag et al. (1996). In short, cells were harvested by centrifugation at $1000 \mathrm{rpm}$ for $2 \mathrm{~min}$ at room temperature. Pellets were washed twice in a Tris medium containing

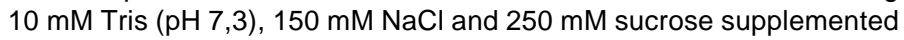
with the mixture of protease inhibitors $(10 \mu \mathrm{g} / \mathrm{ml}$ leupeptin, $5 \mu \mathrm{g} / \mathrm{ml}$ aprotinin, $1 \mathrm{mM}$ PMSF). Final pellets were resuspended in two volumes of cold Tris medium and transferred to chilled Poter homogenizer. Cells were broken by 40 hand strokes. The extent of cell breakage was monitored regularly with microscope inspection. The cell homogenate was centrifuged at $500 \mathrm{~g}$ for $5 \mathrm{~min}$ to remove nuclei and debris. The supernatant was next centrifuged at $100000 \mathrm{~g}$ for $1 \mathrm{~h}$ at $4^{\circ} \mathrm{C}$ to obtain cytosolic and particulate fractions. Protein concentration was determined using Bradford methods (Bradford, 1976). After boiling for $5 \mathrm{~min}$ in Laemmli sample buffer (Laemmli, 1970) the cell fractions were analyzed by SDS-PAGE and Western blotting.

\section{Electrophoresis and Western blot analysis}

Equal amounts of proteins $(30 \mu \mathrm{g})$ from each fraction were separated by $10 \%$ SDS-PAGE with a Hoefer System (Amersham, USA) at pH 8.8 in the presence of SDS (Laemmli 1970). The resolved proteins were transferred to nitrocellulose membranes (Bio-Rad) at $100 \mathrm{~V}$ for $1 \mathrm{~h}$ in transfer buffer containing $25 \mathrm{mM}$ Tris ( $\mathrm{pH} 8.3$ ), $192 \mathrm{mM}$ glycine and 20\% methanol (Towbin et al., 1979) by the Hoefer transfer system (Amersham, USA). Filters were blocked in blocking buffer of $2 \%$ BSA in TBS-Tween for $2 \mathrm{~h}$ and subsequently were incubated with primary antibody overnight 
at $4^{\circ} \mathrm{C}$, and with the HRP conjugated secondary antibody for $1 \mathrm{~h}$ at room temperature. Finally, the immunoreactive protein bands were visualized using the Enhanced Chemiluminescence (ECL) detection system (Amersham, USA).

\section{Research in silico}

Search for putative components of CDC42- GSK33-MARK/PAR1MAPs effector pathway. Macronuclear genome of $T$. thermophila had been sequenced and is available at http://www.tigr.org/tdb/e2k1/ttg/. We performed BLASTp search (Altschul et al., 1997) for proteins that may control the patterned growth and oral replacement in Tetrahymena with reference to the polar differentiation of neural cells. The details of another searches are described in the Result section.

\section{Acknowledgements}

The authors thank Drs Joseph Frankel, Jacek Gaertig, Jytte Nilsson, Potu Rao and Cheryl Ashorn, Leif Rasmussen, and Norman Williams for cell lines used in this study and for gift of antibodies. Many thanks are due to Dr Dorota Dymny-Miecz for help in wortmannin-linked experiments, and to Mrs Marzena Kwiatkowska-Dabrowska for the technical and computer assistance. We are very thankful to Dr M.Kloc for valuable disscusion and comments. This work was supported by the grant from Polish Science Committee \# 2P04C 07428 to Dr Andrzej Kaczanowski.

\section{References}

AHRINGER, J. (2003) Control of cell polarity and mitotic spindle positioning in animal cells. Curr Opin Cel/ Bio/15: 73-81.

ALLEN, R.D. (1967) Fine structure, reconstruction and possible functions of components of the cortex of Tetrahymena pyriformis. J Protozoo/14: 553-565.

ALTSCHUL, S.F., MADDEN, T.L., SCHAFFER, A.A., ZHANG, J., ZHANG, Z., MILLER, W., LIPMAN, D.J. (1997) Gapped BLAST and PSI-BLAST: a new generation of protein database search programs. Nucleic Acids Res. 25: 33893402.

BENTON, R., ST JOHNSTON, D. (2002) Cell polarity: Posterior Par1 prevents proteolysis. Curr Biol.12: R479-R481.

BIERNAT, J., WU, YZ., TIMM, T., ZHENG-FISCHHOFER, Q., MANDELKOW, E., MEIJER, L., MANDELKOW, E.M. (2002) Protein kinase MARK/PAR1 is required for neurite outgrowth and establishment of neuronal polarity. Mol Biol Cel/13: 4013-4028.

BOLLAG, D.M., ROZYCKI, M.D., EDELSTEIN, S.J. (1996) Concentrating protein solution. In: «Protein Methods», Ed. Wiley Publishers pp. 71-93.

BRADFORD, M.M. (1976) A rapid and sensitive method for the quantitation of microgram quantities of protein utilizing the principle of protein-dye binding. Anal Biochem 72: 248-254.

CAU, J., HALL, A. (2005) Cdc42 controls the polarity of the actin and microtubule cytoskeletons through two distinct signal transduction pathways. J Cel/ Sci118: 2579-2587.

CHRISTENSEN, S.T., GUERRA, C.F., AWAN, A., WHEATLEY, D.N., SATIR, P. (2003) Insulin receptor-like proteins in Tetrahymena thermophila ciliary membranes. Curr. Biol. 13: R50-R52.

DOBLE, B.W., WOODGETT, J.R. (2003) GSK-3:tricks of the trade for a multitasking kinase. J. Cell Sci116: 1175-1186.

DREWES, G., NURSE, P. (2003) The protein kinase kin1, the fission yeast orthologue of mammalian MARK/PAR-1, localises to new cell ends, after mitosis and is important for bipolar growth. FEBS Letters 554: 45-49.

DREWES, G., EBNETH, A., PREUSS, U., MANDELKOW, E.M., MANDELKOW, E. (1997) MARK, a novel family of protein kinases that phosphorylate microtubuleassociated proteins and trigger microtubule disruption. Cel/89: 297-308.

EISEN J.A., COYONE R.S, WU M., WU D., THIAGARAYJON M., et al. (2006) Macronuclear genome sequence of the ciliate Tetrahymena thermophila, a model eukaryote. PloS Bio/4: 286-369.

ETIENNE-MANNEVILLE, S., HALL, A. (2003) Cdc42 regulates GSK3beta and adematous polyposis coli to control cell polarity. Nature 421: 753-756.

FRANKEL, J. (1967) Oral morphogenesis and synchronization: a comparison of "synchronous rounding" and synchronous division in Tetrahymena. $J$ Cel/ Biol 35:165 A.

FRANKEL, J. (1969) Participation of the undulating membrane in the formation of oral replacement primordium in Tetrahymena pyriformis. J Protozoo/16: 26-35.

FRANKEL, J. (1970) The synchronization of oral development without cell division in Tetrahymena pyriformis GL-C. J exp Zoo/173: 79-100.

FRANKEL, J. (1989) Pattern formation: Ciliate Studies and Models. Oxford Univ.Press.N.Y.

FRANKEL, J. (1999) Cell Biology of Tetrahymena thermophila. In: Methods in Cell Biology 62 (ed DJ Asai and Forney JD): 27-125.

FRANKEL, J., NELSEN, E.M., MARTEL, E. (1981) Development of the ciliature of Tetrahymena thermophilall Spatial subdivision prior to cytokinesis. Dev Bio/88: 39-54.

HANYU, K., TAKEMASA, T., NUMATA, O., TAKAHASHI, M., and WATANABE, Y. (1995) Immunofluorescence localization of a $25-\mathrm{kDa}$ Tetrahymena EF-hand $\mathrm{Ca}++-$ binding protein, TCBP-25, in the cell cortex and possible involvement in conjugation. Exp. Cell Res. 219: 487-493.

HANYU, K., NUMATA, O., TAKAHASHI, M., WATANABE, Y. (1996) Immunofluorescence localization of a $23-\mathrm{kDa}$ Tetrahymena cacium binding protein, TCBP23, in the cell cortex. J.Biochem. 119:914-919.

HOOPFER, E.D., MCLAUGHLIN, T., WATTS, R.J., SCHULDINER, O., O'LEARY, D.D.M., LUO, L. (2006) Wids protection distinguishes axon degeneration following injury from naturally occurring developmental pruning. Neuron 50: 883-895.

JERKA-DZIADOSZ, M., FRANKEL, J. (1995) The effects of lithium chloride on pattern formation in Tetrahymena thermophila. Dev Biol171: 497-506.

JERKA-DZIADOSZ, M., JENKINS, L.M., NELSEN, E.M., WILLIAMS, N.E., JAECKEL-WILLIAMS, R., FRANKEL, J. (1995) Cellular polarity in Ciliates: persistence of global polarity in a disorganized mutant of Tetrahymena thermophila that disrupts cytoskeletal organization. Dev Biol169: 644- 661.

JERKA-DZIADOSZ, M., STRZYZEWSKA-JOWKO, WOJSA-LUGOWSKA, U., KRAWCZYNSKA, W., KRZYWICKA, A. (2001) The dynamics of filamentous structures in the apical band, oral crescent, fission line and the postoral meridional filament in Tetrahymena thermophila revealed by monoclonal antibody 12G9. Protist 152: 53-67.

JIANG, H., LUO, W., LIANG, X., RAO, Y. (2005) Both the establishment and the maintenance of neuronal polarity require active mechanisms: critical roles of GSK-3- $\beta$ and its upstream regulators. Cel/130: 120-123.

JOHNSON, G.V.W., STOOTHOFF, W.H. (2004) Tau phosphorylation in neural cell function and dysfunction. J. Cell Sci. 117: 5721-5729.

KACZANOWSKA, J., BUZANSKA, L., OSTROWSKI, M. (1993) Relationship between spatial pattern of basal bodies and membrane skeleton (epiplasm) during the cell cycle of Tetrahymena: cda A mutant and anti-membrane skeleton immunostaining. J Eukaryot Microbio/40: 747-754.

KACZANOWSKA, J., JOACHIMIAK, E., BUZANSKA, L., KRAWCZYNSKA, W., WHEATLEY, D.N., KACZANOWSKI, A. (1999) Molecular subdivision of the cortex of dividing Tetrahymenais coupled with the formation of the fission zone. Dev Bio/212: 150- 164.

KACZANOWSKA, J., JOACHIMIAK, E., KIERSNOWSKA, M., KRZYWICKA, A., GOLINSKA, K., KACZANOWSKI, A. (2003) The fenestrin antigen in submembrane skeleton of the ciliate Tetrahymena thermophila is proposed as a marker of cell polarity during cell division and in oral replacement. Protist 154: 251-264.

KACZANOWSKI, A. (1975) A single-gene-dependent abnormality of adoral membranelles in Tetrahymena pyriformis, species 1. Genetics 81: 631-639.

KACZANOWSKI, A (1976) An analysis of MP gene affected morphogenesis in' Tetrahymena pyriformis, syngen 1 (species1) Ciliates. J Exp Zoo/196:215230.

KACZANOWSKI, A. (1978) Gradients of proliferation of ciliary basal bodies and the determination of the position of the oral primordium in Tetrahymena. Jexp Zool 204: $417-430$

KIERSNOWSKA, M., GOLINSKA, K. (1996) Pattern of phosphorylated structures in the Morphostatic ciliate Tetrahymena thermophila: MPM2 immunogold labeling. Acta Protozoo/35: 297- 308.

KOSUGA, S., TASHIRO, E., KAJIOKA, T., UEKI, M., SHIMIZU, Y., IMOTO, M. (2005) GSK3 $\beta$ directly phosphorylates and activates MARK2/PAR-1. J. Biol.Chem. 280: 42715-42722. 
KOZMA, S.C., THOMAS, G. (2002) Regulation of cell size in growth, development and human disease:PI3K,PKB and S6K. BioEssays 24:65-71.

KOVACS, P., PALLINGER, E. (2003) Phosphatidylinositol 3-kinase-like activity in Tetrahymena. Effects of wortmannin and LY 294002. Acta Protozoo/42: 277285.

LA CARBONA, S., ALLIX, C., PHILLIPE, M, LE GOFF, X. (2004) The protein kinase kin 1 is required for cellular symmetry in fission yeast. Biol Cel/96: 169-179.

LAEMMLI, U.K. (1970) Cleavage of structural proteins during the assembly of the head of bacteriophage T4. Nature 277: 680-685.

LEONDARITIS, G., TIEDTKE, A., GALANOPOULOU, D. (2005) D-3 phosphononositides of the Ciliate Tetrahymena: Characterization and study of their regulatory role in lysosomal enzyme secretion. Bioch Biophys Acta 1745: 330-341.

MATUI, T., TOKURAKU, K., SHIMAZAKI, Y., KOTANI, S. (2004) Identification of an XMAP215-related 60kDa polypeptide as a major microtubule-associated protein in Tetrahymena pyriformis Japanise. J Protozool.37:11-18.

NANNEY, D.L. (1975) Pattern of basal bodies addition in ciliary rows in Tetrahymena. J Cell Bio/65: 503-512.

NELSEN, E.M., FRANKEL, J., MARTEL (1981) Development of the ciliature of Tetrahymena thermophila I Temporal coordination with oral development. Dev Bio/88: 27-38.

NELSEN, E.M., WILLIAMS, N.E., Yi H, KNAAK, J., FRANKEL, J. (1994) "Fenestrin" and conjugation in Tetrahymena thermophila. J Eukaryot Microbiol. 41: 483495.

NG, S.F. (1978) Directionality of microtubule assembly: An in vivo study with the Ciliate Tetrahymena. J. Cell Sci33: 227-234.

NG, S.F. (1979) Unidirectional regeneration is an intrinsic property of longitudinal microtubules in Tetrahymena-an in vivo study. J Cell Sci36:109-119.

NG, S.F., FRANKEL, J. (1977) $180^{\circ}$ rotation of ciliary rows and its morphogenetic implications in Tetrahymena pyriformis. Proc Natl Acad Sci. USA 74: 11151119.

PALMA, K., ZHANG, Y., LI, X. (2005) An importin alpha homolog MOS6 plays an important role in plant innate immunity. Curr Bio/15: 1129-1135.

PENG, C.Y., GRAVES, P.R., OGG, S., THOMA, R.S., BYRNES, M.J., WU, Z, STEPHENSON, M.T., PIWNICA-WORMS, H. (1998) C-TAK1 protein kinase phosphorylates human Cdc25C on serine 216 and promotes 14-3-3 protein binding. Cell Growth \&Differ. 9:197-208.

PETIOT, A., OGIER-DENIS, E., BLOMMAART, E.F., MEIJER, A.J., CODOGNO, P. (2000) Distinct classes of phosphatidylinositol 3'-kinases are involved in signaling pathways that control macroautophagy in HT-29 cells. J. Biol. Chem. 275: 992-998.

RYALS, P.E., SMITH-SOMERVILLE, H.E., BUHSE, H.E. jr. (2002) Phenotype switching in polymorphic Tetrahymena: a single-cell Jekyll and Hyde. Int Rev Cytol. 212: 209-238.

SCHONEGG, S., HYMAN, A.A. (2006) CDC42 and RHO-1 coordinate acto-myosin contractility and PAR protein localization during polarity establishment in $C$. elegans embryos. Development 133: 3507-3516.

STRZYZEWSKA-JOWKO I., JERKA-DZIADOSZ, M., FRANKEL, J. (2003) Effect of alteration in the global body plan on the deployment of morphogenesis-related protein epitopes labeled by the monoclonal antibody 12G9 in Tetrahymena thermophila. Protist 154:71-90.
TASSAN, J.-P., LE GOFF, X. (2004) Review: An overview of the kin1/Par1/mark family. Biol of Cel/96: 193-199.

THAZHATH, R., LIU, C., GAERTIG, J. (2002) Polyglycylation domain of $\beta$ tubulin maintains axonemal architecture and affects cytokinesis in Tetrahymena. Nat. Cell Bio/4:256-259.

THAZHATH, R., JERKA-DZIADOSZ, M., DUAN, J., WLOGA, D., GOROVSKY, M.A., FRANKEL, J., GAERTIG, J. (2004) Cell context-specific effects of the beta-tubulin glycylation domain on assembly and size of microtubular organelles. Mol Biol Cel/ 15: 4136-4147.

TIEDTKE, A., HUNSELER, P., RASMUSSEN, L. (1988) Growth requirements of a new food-vacuole-less mutant of Tetrahymena. Eur J Protistol.23: 350-353.

TOWBIN, H., STAEHELIN, T., GORDON, J. (1979) Electrophoretic transfer of proteins from polyacrylamide gels to nitrocellulose sheet: Procedure and some applications. Proc Natl Acad Sci USA 76: 4350-4354.

WANG, C., DENG, L., HONG, M., GR, AKKARAJU., INOUE, J.-I., CHEN, Z.J. (2001) TAK1 is an ubiquitin- dependent kinase of MKK and IKK. Nature 412: 346-351.

WAKEFIELD, J.G., STEPHENS, D.J., TAVARE, J.M. (2003) A role for glycogen synthase kinase-3 in mitotic spindle dynamics and chromosome alignment. $J$ Cell Sci116: 637-646.

WALLINGFORD, J.B, HABAS, R. (2005) The developmental biology of Dishevelled. an enigmatic protein governing cell fate and cell polarity. Development 132: 4421-4436.

WESTENDORF, J.M, RAO, P.N., GERACE, L.(1993) Cloning of cDNAs for Mphase phosphoproteins recognized by the MPM-2 monoclonal antibody and determination of the phosphorylated epitope. Proc Nat/ Acad. Sci USA91: 714718.

WIGGIN, G.R, FAWCETT, J.P., PAWSON, T. (2005) Polarity proteins in axon specification and synaptogenesis. Dev. Cel/8:803-816.

WILLIAMS, N.E, SCHERBAUM, O.H. (1959) Morphogenetic events in normal and synchronously dividing Tetrahymena pyriformis GL. J Embryol Exp Morph 7:241-256.

WILLIAMS, N.E., FRANKEL, J. (1973) Regulation of microtubules in Tetrahymena I. Electron microscopy of oral replacement. J Cel/ Bio/56:441-457.

WILLIAMS, N.E., NELSEN, E.M. (1973) Regulation of microtubules in Tetrahymena. II Relation between turnover of microtubule proteins and microtubule dissociation and assembly during oral replacement. J Cel/ Bio/56: 458-465.

WILLIAMS, N.E., HONTS, J.E., JAECKEL-WILLIAMS, R.F. (1987) Regional differentiation of the membrane skeleton in Tetrahymena. J Cell Sci 87: 457-463.

WILLIAMS, N.E., HONTS, J.E., KACZANOWSKA. J. (1990) The formation of basal body domains in the membrane skeleton of Tetrahymena. Development 109: 935-942.

WILLIAMS, N.E., HONTS, J.E., DRESS, V.M., NELSEN, E.M., FRANKEL, J. (1995) Monoclonal antibodies reveal complex structure in the membrane skeleton ofTetrahymena. J Eukaryot Microbio/42: 422-427.

WILLIAMS, N.E. (2004) The epiplasm gene EPC1 influences cell shape and cortical pattern in Tetrahymena thermophila. J.Eukaryot.Microbiol. 51: 201-206.

ZACKROFF, R.V., HUFNAGEL, L.A. (2001) Wortmannin, phagocytosis and antiactin drug resistance in Tetrahymena thermophila. J Eukaryot Microbio/ Abstract 33 . 


\section{Related, previously published Int. J. Dev. Biol. articles}

See our recent Special Issue Developmental Biology in Poland edited by Kloc, Maleszewski and Tarkowski at: http://www.ijdb.ehu.es/web/contents.php?vol=52\&issue=2-3

See our Special Issue Mammalian Reproduction \& Development in honor of Anne McLaren and edited by Brigid Hogan at: http://www.ijdb.ehu.es/web/contents. php?vol=45\&issue $=3$

Shaping the mammalian auditory sensory organ by the planar cell polarity pathway Michael Kelly and Ping Chen

Int. J. Dev. Biol. (2007) 51: 535-547

Wnt signaling in hydroid development: ectopic heads and giant buds induced by GSK-3beta inhibitors

Werner Müller, Uri Frank, Regina Teo, Ofer Mokady, Christina Guette and Günter Plickert

Int. J. Dev. Biol. (2007) 51: 211-220

Analysis of the role of the Rac/Cdc42 GTPases during planar cell polarity generation in Drosophila

Silvia Muñoz-Descalzo, Azucena Gómez-Cabrero, Marek Mlodzik and Nuria Paricio

Int. J. Dev. Biol. (2007) 51: 379-388

Effects of microgravity on cell cytoskeleton and embryogenesis Susan J. Crawford-Young

Int. J. Dev. Biol. (2006) 50: 183-191

A hypothesis linking low folate intake to neural tube defects due to failure of post-translation methylations of the cytoskeleton Natalie K. Björklund and Richard Gordon

Int. J. Dev. Biol. (2006) 50: 135-141

Formation of a successional dental lamina in the zebrafish (Danio rerio): support for a local control of replacement tooth initiation Ann Huysseune

Int. J. Dev. Biol. (2006) 50: 637-643

Patterning a multi-headed mutant in Hydractinia: enhancement of head formation and its phenotypic normalization.

Werner A Müller, Regina Teo and Frank Möhrlen

Int. J. Dev. Biol. (2004) 48: 9-15

Flamingo, a cadherin-type receptor involved in the Drosophila planar polarity pathway, can block signaling via the canonical wnt pathway in Xenopus laevis.

Richard Morgan, Ali-Morsi El-Kadi and Christopher Theokli

Int. J. Dev. Biol. (2003) 47: 245-252

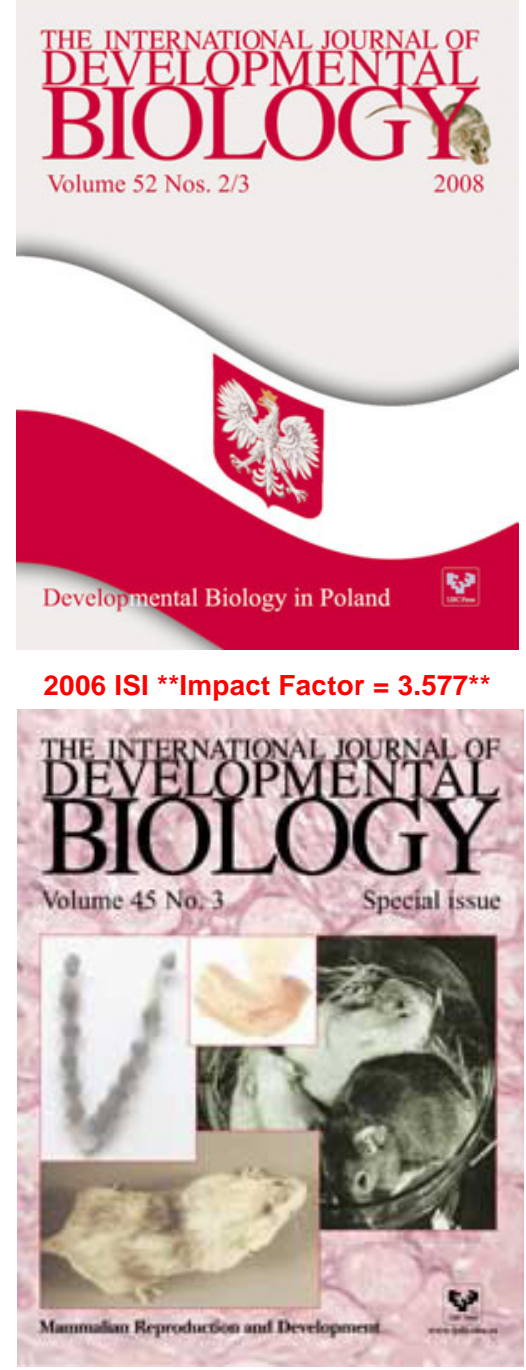

